\title{
The Development of Learning Media Based on Android Using Crossword Puzzles to Improve Student's Vocabulary Skill
}

\author{
Rini Yudiati ${ }^{1 *}$, Hanifatur Rizqi ${ }^{2}$ \\ ${ }^{1}$ Health Faculty, University Wiraraja, 69451, Indonesia \\ ${ }^{2}$ Civil Engineering Faculty, University Wiraraja, 69451, Indonesia \\ *Email: riniyudiatisusilo@gmail.com
}

\begin{abstract}
The aim of this study was 1) to develop learning media based on android using crossword puzzles to improve vocabulary skills, 2) determine the feasibility of learning media based on android using English crossword puzzles from material experts, media experts, and English learning, 3) Knowing the response of class XI students of SMK Negeri 1 Sumenep to the development of Learning Media based on Android Using English Crossword Puzzles. The research method used is the ADDIE development method. The research subjects involved were class XI students of SMKN 1 Sumenep, while the object under study was the development of learning media in the form of learning media based on Android using crossword puzzles to improve vocabulary skills. The results showed that the students' conclusions about the media in terms of aspects viewed from software, learning aspects and design aspects obtained a score of 4, 37 which lies in the range $X>4.20$ with a very feasible category.
\end{abstract}

Keywords: Learning Media, Crossword Puzzle, Vocabulary.

\section{INTRODUCTION}

Education cannot be separated from the teaching and learning process. One of the components that can support the success of the teaching and learning process is the use of instructional media. According toWina Sanjaya, learning media are all tools and materials that can be used to achieve educational goals [1]. Teachers can take advantage of manual or technology-based learning media in the learning proces. Learning media consists of three types, namely audio media, visual media, and audio visual media [2].

Many factors influence the achievement of learning objectives in the teaching and learning process including educators, students, the environment, methods or techniques and learning media. Learning media is a very good factor in the world of education. With the availability of learning media, teacher educators can create various classroom situations. Even these learning tools or media can then help teachers bring the outside world into the classroom.

The world of education is inseparable from the learning process which includes teachers, students, and the learning environment which influence each other in order to achieve learning objectives. Media is one of the supporting factors for the achievement of learning objectives. This is related to the use of appropriate and varied media in the learning process which can increase learning motivation and can reduce students' passive attitudes [3].

The development of mobile technology is so fast, one of the most commonly used mobile devices is cell phones. Nearly $90 \%$ of students must already have one cell phone or some even have more than one cell phone. If the number of students who own and use mobile devices, the greater the opportunity to use technology devices in education. Learning media that utilize cellphone technology is called mobile learning (MLearning). Mobile learning is an alternative development of learning media. The presence of mobile learning is intended as a complement to learning and provides opportunities for students to study material that is not well mastered anywhere and anytime [4].

Crossword puzzle is a game that is played by filling in the empty spaces in the shape of a box with letters to form a word according to the clue. The purpose of the crossword puzzle game is to eliminate or reduce boredom in learning and create a pleasant teaching and learning 
atmosphere because it seems relaxed but still focused on the material.

Crossword puzzle learning media has advantages, namely (1) it can be useful for sharpening the brain, reasoning, training logic, and patience so that it will facilitate the process of transferring knowledge to students; (2) can activate students in learning activities; (3) can improve students' thinking and concentration skills; (4) can make it easier for students to remember the subject matter presented; (5) can eliminate students' boredom during teaching and learning activities [5]. Therefore, the Crossword Puzzle Learning Media needs to be developed as a learning medium.

One of the media that is very interesting is crossword puzzles. The crossword puzzle game media is a game by filling in the boxes with letters to form a word, either vertically or horizontally.

Basically, English is also considered boring by students. The reason is a way to pronounce properly and correctly, because the letters with speech must be different. Even though learning English in the classroom has created a pleasant situation, there are still obstacles faced by students. This is due to the lack of students mastering English vocabulary.

Vocabulary is one of the English learning materials which has an important role for students to master the subject matter. Mastery of Vocabulary affects students' thinking and creativity, so that vocabulary mastery can determine the quality of a student in speaking English.

Vocabulary is something that is fundamental for students to be able to understand the material presented by the teacher. However, in English it is not easy to pronounce it word for word. As stated by previous researchers by Alfiani Prihastuti with the title Development of Learning Media for English Vocabulary Based on Cross Puzzles said that many students were not able to speak English well, which made it difficult to absorb information or knowledge. from books or media that use English.

Based on the problems described above, the authors chose and conducted research "Development of Learning Media Based on Android using Crossword Puzzles To Improve Student's Vocabulary Skills".

The special purpose of this research is to make aplication about learning media based on android that will be designed using Crossword Puzzle for SMK Negeri 1 Sumenep. This research process requires steps such as analysis, material collection, experts, try out, and making applications.

Product development using the Addie model is good enough. That's because the Addie model has 5 steps which are quite sufficient to take. Addie's model consists of Analysis, Design, Development, Implementation, and Evaluation can be seen in Figure 1.

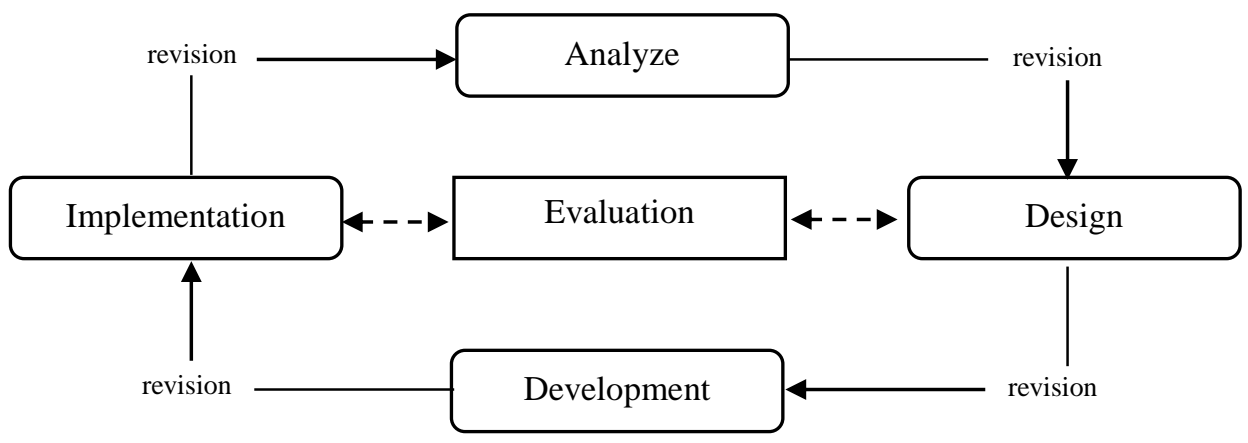

Figure 1. Research step (Addie's model)

\section{MeTHOD}

The research method used is the ADDIE development method. Research and development research methods are research methods used to produce certain products and product validity [6]. Meanwhile, accordingto Sujadi Research and Development is a processor steps to develop new products, or make perfect products that can be justified [7].

The development of learning media based on Android using Crossword Puzzle is an adaptation and modification of the research and development steps of the ADDIE model with 5 stages, namely, 1) Analysis, 2) Design, 3) Development, 4) Implementation, and 5)
Evaluation. The detailed implementation of the entire research development procedure can beseen in thefollowingdescription.

\subsection{Analysis}

Needs analysis deals with the problems and characteristics of students, hardware, and software. The results of class observations and interviews with elementary English teachers, it was found that student learning activities in class XI TKJ 1, TKJ 2, and MM 1 were still low, 83 out of 100 students or the equivalent of $83 \%$ of students did not dare to answer. questions asked by the teacher without having to be 
appointed first. In addition, students lack confidence in answering questions from the teacher or asking questions to the teacher about what material they do not really understand. They also lack confidence to refute in appropriate opinions from other friends who answer questions given by the teacher. Furthermore, from the results of observations, it appears that there is a lack of development of instructional media by teachers and schools. The limitations of learning media make students feel bored and tend not to pay attention to the explanations given by the teacher.

The hardware used to make this learning media are: (a) Windows 10 Pro 64-bit, (b) AMD A8-6410 APU, (c) 8 GB RAM, (d) 1.5 TB hard disk, and (e) SmartPhone. Beside that, the software used is as follows: (a) Windows OS, (b) WEB Browser, (c) Text Editor, (d) Composer, and (e) Android SDK.

\subsection{Design}

Researchers compile an instrument to assess the feasibility of learning media. The instrument used to assess the quality of learning media based on android using crossword Puzzle was a questionnaire containing an assessment of learning media based on android using Crossword Puzzle. In this stage, the researcher made a product assessment questionnaire grid. The product assessment instrument of this study was a questionnaire (check list) for material experts, media experts, practitioners of Basic English learning and a questionnaire for students as presented in Table 1. The results of the material expert's feasibility assessment if presented as a diagram can be seen in Figure 2.

Table 1. Results of the material expert feasibility assessment

\begin{tabular}{ccccc}
\hline No & Assessment Aspect & Score & Score rate & Category \\
\hline 1 & Question & 42 & 4,67 & Very feasible \\
2 & Language & 15 & 5 & Very feasible \\
3 & Implementation & 25 & 5 & Very feasible \\
& Total & $\mathbf{8 2}$ & $\mathbf{4 , 8 2}$ & Very feasible \\
\hline
\end{tabular}

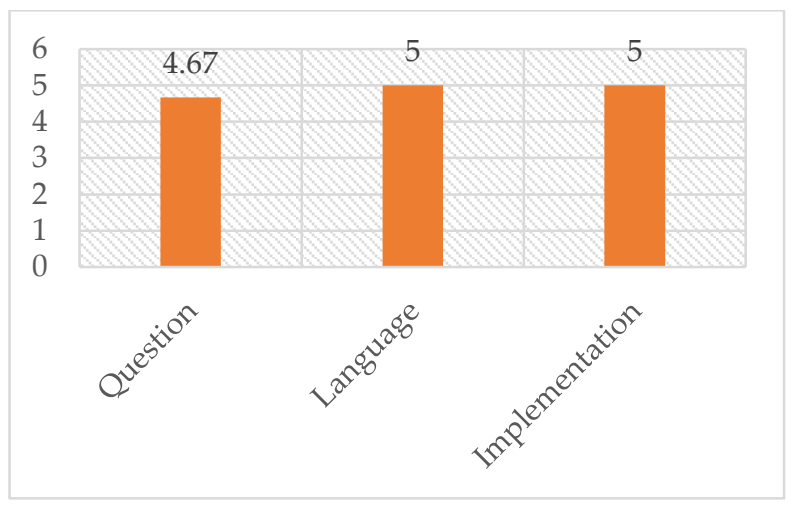

Figure 2. Diagram of the results of the material expert eligibility assessment

The feasibility assessment is carried out by media experts by collecting suggestions or opinions from media experts to make revisions. The questionnaire is distributed using a Likert scale with 5 alternative answers, namely Strongly Agree, Agree, Disagree, Disagree, and Strongly Disagree. The questionnaire for media experts has 20 assessment indicators which are grouped into 2 aspects, covering aspects of software engineering and aspects of visual communication. The results of the recapitulation and analysis of the feasibility assessment can be seen in full in Appendix 13, for the average results of the feasibility assessment of material experts can be seen in Table 2. The result of Media Expert Feasibility Assessment if presented in a diagram can be seen in Figure 3.

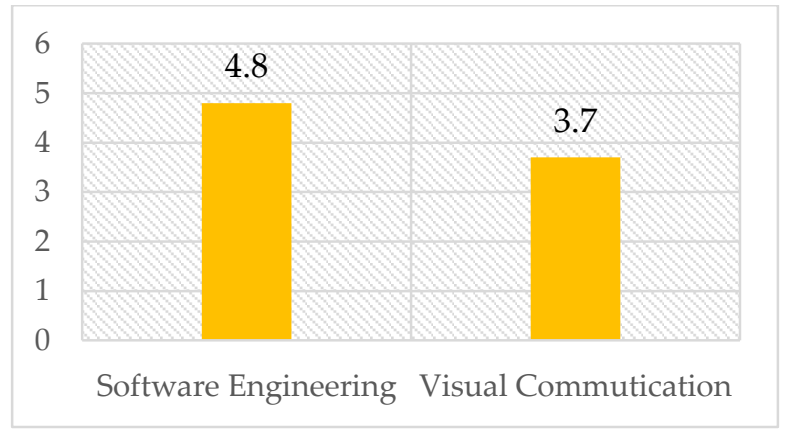

Figure 3. Diagram of the result of feasibility assessment of media experts

Table 2. Result of media expert feasibility assessment

\begin{tabular}{ccccc}
\hline No & AssessmentAspect & Score & Score Rate & Category \\
\hline 1 & Software engineering & 48 & 4,80 & Very Feasible \\
2 & Visual Communication & 37 & 3,70 & Very Feasible \\
& Total & $\mathbf{8 5}$ & $\mathbf{4 , 2 5}$ & Very Feasible \\
\hline
\end{tabular}


The initial media which had been assessed for its feasibility by material experts and media experts was then assessed for its eligibility by 1 practitioner of English learning at SMK Negeri 1 Sumenep, namely Drs.
Ec. Aris Munandar, S.Pd., M.Pd. This result can be seen in Table 3. The result of learning Practitioner Assessment if presented as a diagram can be seen in Figure 4.

Table 3. Results of the Study Practitioner Feasibility Assessment

\begin{tabular}{ccccc}
\hline No & Assessment Aspect & Score & Score Rate & Category \\
\hline 1 & Software Engineering & 38 & 4,75 & Very Feasible \\
2 & Learning Design & 75 & 4,69 & Very Feasible \\
3 & Visual Communication & 38 & 4,75 & Very Feasible \\
& Total & $\mathbf{1 5 1}$ & $\mathbf{4 , 7 2}$ & Very Feasible \\
\hline
\end{tabular}

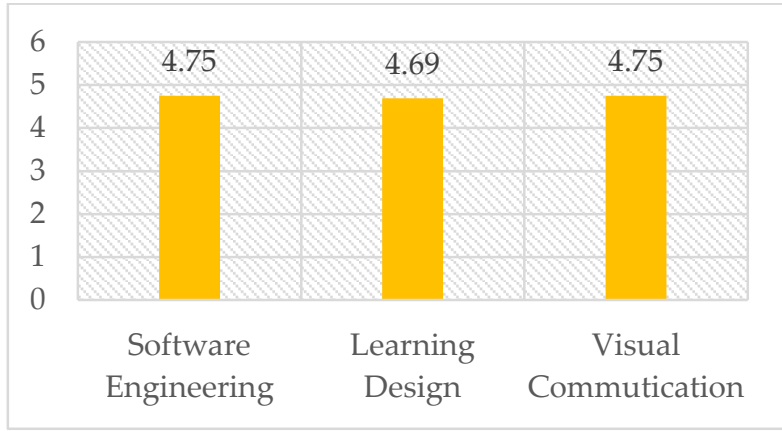

Figure 4. Diagram of learning practitioner feasibility assessment result
Based on the results of the feasibility assessment of each validator on the Learning Media for Educational Games Crossword Puzzle in English, the overall recapitulation is obtained. The result of recapitulation of the eligibility of the Overall expert assessment can be seen in Table 4. Revisions given by experts to Learning Media are used to minimize errors and eligibility for use. Revisions are made based on suggestions and input provided by Material Experts, Media Experts, English Learning Practitioners and students as potential users.

Table 4. The results of recapitulation of the eligibility of the overall expert assessment

\begin{tabular}{llccccc}
\hline No & \multicolumn{1}{c}{ Score Aspect } & $\begin{array}{c}\text { Material } \\
\text { Expert }\end{array}$ & $\begin{array}{c}\text { Media } \\
\text { Expert }\end{array}$ & $\begin{array}{c}\text { Practitioner } \\
\text { Expert }\end{array}$ & Rerata & Category \\
\hline 1 & Learning Design & 4,82 & & 4,69 & 4,76 & Very feasible \\
2 & Software Engineering & & 4,80 & 4,75 & 4,52 & Very feasible \\
3 & Visual Communication & 3,70 & 4,75 & 4,48 & Very Feasible \\
\multicolumn{2}{r}{ Average Total Score } & & & $\mathbf{4 , 5 9}$ & Very Feasible \\
\hline
\end{tabular}

\subsection{Development}

This stage the learning media product is made according to a predetermined format, making media using hardware with Windows 10 Pro 64-bit specifications, AMD A8-6410 APU, 8 GB RAM, 1.5 TB hard disk, VGA AMD Radeon (TM) R5 Graphics. All components that have been prepared at the design stage are assembled into one media unit using the Windows OS, WEB Browser, Text Editor, Composer, Android SDK. All components are assembled into one media unit according to the storyboard. At the stage of making the media in this study, there are 4 activities, namely game design, coding, testing, and deploying.

\subsection{Implementation}

After the revision is made, the next step is to carry out the implementation in field trials. Before conducting the socialization, the researcher distributed media to students using the Playstore and the SHAREit and Data Cable applications, assisted by two observers who were also students of the University of Wiraraja, Madura. Applications that have been obtained by students can then be installed by students online. Furthermore, the researcher conducts socialization about the media, the researcher explains in detail the things that are in the learning media. At this stage the researcher also measures the initial learning activities before implementing the media. The recapitulation of the measurement results of Early Learning Activitie can be seen in Table 5.

Table 5. Recapitulation of the measurement results of early learning activity

\begin{tabular}{ccc} 
& \multicolumn{2}{c}{ Report } \\
Mean & Nre_Test & \\
\hline 64.8400 & 100 & Std. Deviation \\
\hline
\end{tabular}


Based on the results of the above observations it was found that the average student learning outcomes score was 64.8 out of a total of 100 students. In the field trial phase, the media was tested on 100 students of class XI TKJ 1, TKJ 2, and MM 1 at SMK Negeri 1 Sumenep. In this trial, researchers distributed student assessment questionnaires to the media in terms of software engineering aspects, learning design aspects and visual communication aspects. Based on the results of student assessments in the field trial can be seen in Table 6 .

Table 6. Results of Student Responses Assessment in Field Trials

\begin{tabular}{clccc}
\hline No & Assessment Aspect & Total Score & Score Rate & Category \\
\hline 1 & Software Engineering & 3642 & 4,55 & Very Feasible \\
2 & Learning Design & 3713 & 4,64 & Very Feasible \\
3 & Visual Communication & 4480 & 4,48 & Very Feasible \\
& Total & $\mathbf{1 1 8 3 5}$ & $\mathbf{4 , 5 5}$ & Very Feasible \\
\hline
\end{tabular}

At this stage the researcher also measures the final Learning Activity after implementing the media. The following is the result of student assessments in the field trial presented in Table 7. Then, Paired Samples Statistics is presented in Table 8 .

Table 7. Recapitulation of final learning activity measurement results

\begin{tabular}{ccc} 
& \multicolumn{2}{c}{ Report } \\
Post_Test & & \\
Mean & N & Std. Deviation \\
\hline 81.7800 & 100 & 3.83387 \\
\hline
\end{tabular}

Table 8. Paired Samples Statistics

\begin{tabular}{lllccc}
\hline & & Mean & N & Std. Deviation & Std. Error Mean \\
\hline Pair 1 & Pre_Test & 64.8400 & 100 & 3.07719 & .30772 \\
& Post_Test & 81.7800 & 100 & 3.83387 & .38339 \\
\hline
\end{tabular}

\subsection{Evaluation}

This instrument test was carried out even though the questionnaire used was a used questionnaire in order to find out whether the instrument used was indeed able to be used in accordance with the expert's opinion (expert judgment) or not. In this instrument test, it was carried out with two tests.

It is known that the results of the validity test on the indicators of the learning design aspects of items 5, 9, 13, 15 and 22 are invalid because they have a value $<$ r-table, in addition to these items on each of the indicators used to measure student responses to the media are declared valid.

The results of the r-table calculation obtained are interpreted by the reliability level of the correlation coefficientaccordingto Sugiono [8]. The results of the reliability calculation showed that the measuring instrument or questionnaire used has a value between 0.800 and 1,000 , which is 0.901 . Based on these data, it can be concluded that the research questionnaire is reliable or has a very high internal consistency.
In the data that has been presented regarding the validity and reliability of the questionnaire in this study, the questionnaire used as a measuring tool in general can be used and there are only 4 missing items, namely items $5,9,13,15$ and 22 . Thus, the data that has been collected can be continued to answer the problem formulation.

Researchers conduct evaluations to measure the success of product development goals. This evaluation was carried out to determine the increase in learning activities after the use of instructional media for educational games of crossword puzzles in English in basic English subjects. At the evaluation stage, a product effectiveness test is carried out by comparing the results of observations before and after implementing the product. In this study, researchers conducted a product effectiveness test by comparing the results of initial observations before implementing the product with the results of final observations after implementing the product. Based on the results of observations andIt is known that the Significance Value (2-tailed) $.000<0.05$, this indicates that there is a very significant difference in treatment between the results of the initial observation or before the implementation of the product with the final 
observation or according to the implementation of the product.

\section{RESUlt AND DisCUSSION}

The material expertasseessed and shows that when viewed from the question aspect the average value obtained is 4.67 which is included in the Very Appropriate category, while the language aspect gets an average value of 5 which is included in the Very Appropriate category, then from the implementation aspect the results are obtained. assessment with an average value of 5 which is in the Very Eligible category. Overall, the results of the feasibility assessment by material experts seen from the aspects of the questions, language, and implementation obtained an overall average value of 4.82 which falls within the range of values $X>4.20$ so that the feasibility level of learning media is based on the feasibility assessment of material experts, Game Learning Media Educational crossword puzzles in English fall into the Very Appropriate category.

The resul of media expert assessment showed that in terms of the software engineering aspect, the average value obtained is 4.80 which is included in the Very Appropriate category, while from the visual communication aspect, the results are obtained with an average value of 3.70 which is in the Very Appropriatecategory. The total results of the feasibility communication by media experts seen from the software and visuals obtained a total average value of 4.25 which is included in the $X$ value assessment $>4.20$ so that the feasibility level of the Learning Media Educational Game Cross Puzzle English is based on the results of expert eligibility media is in the Very Eligible category.

The practitioner also showed that when viewed from the software engineering aspect, the average value obtained is 4.75 which is included in the Very Appropriate category, then when viewed from the aspect of learning design the average value is 4.69 which is included in the category. Very Feasible, whereas from the aspect of visual communication the results of the assessment were obtained with an average value of 4.75 which is in the Very Appropriate category. Overall, the results of the feasibility assessment by practitioners of English learning seen from software engineering, learning design and visual communication obtained an overall average value of 4.72 which falls within the range of values $X>4.20$ so that the feasibility level of learning media for learning educational games. The English Cross based on the feasibility assessment of English learning practitioners falls into the Very Appropriate category.

The results of observations of measurement of students' final learning activities, it is known that the student's assessment of student learning activities obtained an overall average score of 81.7 from a total of 100 students. This indicates that there is a very high significance of the Android-based learning media using crossword puzzles application which is much higher seen from the results of initial observations, namely 64.8, which means that this media is very feasible.

The researcher showed that the results of the validity test on the indicators of the learning design aspects of items 5, 9, 13, 15 and 22 are invalid because they have a value of <r-table, in addition to these items on each indicator used to measure student responses to the media are declared valid.

The results of this development research are in accordance with the theory described by Zainal Arifin, that learning is only possible if active students experience it themselves[9]. There are many ways that can be done to increase student learning activities, one of which is the use of learning media. This is in line with what is stated by Ngalim Purwanto which states that the teacher factor and the way of teaching is the most important factor in learning [10]. The way of teaching the teacher in question is the ability to use the tools provided by the school, including the use of learning media in the classroom. According to Ega Rima Wati the general benefit of learning media is that students become more active so that they do more learning activities, not only listening to the teacher but also being active in anactivity [11].

\section{Conclusion}

Based on the assessment carried out by material experts in the Learning media based on android using Crossword Puzzle an average overall score of 4.84, Media expert assessment overall score is 4,25, learning practitioner assessment an average overall score of 4.72, and Student's response on learning media overall score is it's mean Very feasible". Based on the Significance Value (2-tailed) $.000<0.05$, this indicates that there is a very significant difference in treatment between the results of initial observations or before implementation of the product with the final observation or according to product implementation.

Based on the values above, the results of Material Experts, Media Experts, Educational Practitioners and Student Responses and the significance value test (2tailed) show that the English Cross Puzzle Educational Game Learning Media was developed based on the assessment of aspects of software engineering, design Visual learning and communication is very feasible to use to improve Basic English Learning Activities.

\section{ACKNOWLEDGMENT}

Thank you to the Deputy for Strengthening Research and Development of the Ministry of Research and 
Technology / National Research and Innovation Agency of the Republic of Indonesia as a source of funding for the PDP Program for the 2020 Fiscal year according to Decree Number 8 / EI / KPT / 2020.

This research was funded by the Directorate of research and community service with LLDIKTI region VII based on decision number 083/SP2H/LT/DRPM/2020.

\section{REFERENCES}

[1] W. Sanjaya, Strategi Pembelajaran Berorientasi Standar Proses Pendidikan. Jakarta: Kencana Prenada Media Group, 2014.

[2] J. Suprihatiningrum, Strategi Pembelajaran: Teori \& Aplikasi. Yogyakarta: Ar-Ruzz Media, 2014.

[3] D. Hardianto, "Media Pendidikan sebagai Sarana Pembelajaran yang Efektif," Maj. Ilm.

Pembelajaran, vol. 1, no. 1, pp. 95-104, 2005, Accessed: Feb. 12, 2021. [Online]. Available: https://journal.uny.ac.id/index.php/mip/article/vie w/5972.

[4] P. W. Wirawan, "Pengembangan Kemampuan E-
Learning Berbasis Web ke dalam M-Learning," $J$. Masy. Inform., vol. 2, no. 4, pp. 21-26, Mar. 2012, doi: 10.14710/jmasif.2.4.21-26.

[5] M. Silberman, Active Learning: 101 Metode Pembelajaran Aktif. Yogyakarta: Pustaka Insan Madani, 2009.

[6] Sugiyono, Metode Penelitian Pendidikan: Pendekatan Kuatitatif, Kualitatif, dan R\&D. Bandung: Alfabeta, 2016.

[7] Sujadi, Penelitian dan Pengembangan atau Research and Development $(R \& D)$. Jakarta: Rineka Cipta, 2003.

[8] Sugiyono, Metode Penelitian Pendidikan Pendekatan Kuantitatif, Kualitatif dan R\&D. Bandung: Alfabeta, 2013.

[9] Z. Arifin, Evaluasi Pembelajaran. Bandung: PT. Remaja Rosdakarya, 2016.

[10] N. Purwanto, Psikologi Pendidikan. Bandung: PT. Remaja Rosdakarya, 2014.

[11] E. R. Wati, Ragam Media Pembelajaran. Jakarta: Kata Pena, 2016. 